\title{
Educação de rua:
}

\section{os meninos e o tempo}

\author{
CLÁUdiA VIRGínIA MEDEIROS ALMEIDA
}

$\mathrm{H}$

OJE É O MEU primeiro dia de trabalho no Centro Alternativo de Apoio a Meninos e Meninas de Rua: o Centro Erê(1). Fico lendo material relativo aos atendimentos feitos pela entidade. Observo uns meninos passando para pegar camisinhas com o educador da Casa. Ele me disse achar que alguns meninos vêm ao Centro pegar para vendê-las aos travestis, por preço mais barato; em média a $\mathrm{R} \$ 0,50$ a tira com três preservativos. Átila comenta que é muito difícil controlar o uso e essa venda. A venda só acontece em casos quando o travesti não pôde ir ao posto buscar os preservativos ou não comprou.

Compreendo a necessidade de tomar notas sobre o dia a dia do trabalho de rua. Já é hábito antigo meu, vindo de outros trabalhos. A velocidade com que as situações acontecem não me permitiria ter gravado na memória fatos que precisam ser registrados. Porém, em muitos momentos não será possível ter essas notas com assiduidade diária e sei que serão vários os motivos a justificarem isso (22.11.99).

23.11.99 - Terça-Feira. Ida à rua: reconhecimento dos locais e para que os meninos me conheçam. Os pontos são: a Praça dos Martírios, a Praça Sinimbú, Praça Deodoro, Praça da Faculdade e Feira do Rato (região do Mercado da Produção). Na Praça dos Martírios conheço Pedro, Antônio, Nilo, e outros que ainda não sei dos nomes.

\section{Uma pequena nota}

LUÍZ SÁVIO DE ALMEIDA

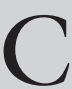
LÁUDIA trabalhava comigo junto aos Kariri-Xocó. Depois veio a idéia de ir para a rua. Admirei a coragem. Conversamos sobre seu trabalho. Tinha que mudar: de índio para as ruas de Maceió. Sugeri que não perdesse muito tempo e que aproveitasse para escrever uma história das ruas, mergulhada por baixo nos escondidos do Paraíso das Águas ou Cidade Sorriso e, então, apareceu este Diário. É uma historiografia carrasquenta como a pereba e dolorosa como a facada. Sugeri que até mesmo evitasse corrigir o português pois soaria falsa. Na última vez que a vi, Cláudia estava doente: levou uma tremenda pedrada na cabeça e esteve ruim. Voltou, continua escrevendo sobre a história e encontrando-se com o menino que jogou a pedra. Tudo é assim mesmo; ninguém recebe duas vezes a mesma pedrada.

Cláudia Virgínia Medeiros Almeida, 26 anos, é graduada em História pela Universidade Federal de Alagoas, após ter apresentado o Trabalho de Conclusão de Curso intitulado: 'Ele deve estar chupando cana: um estudo sobre o desaparecimento e morte de crianças e adolescentes, em situação de risco, na cidade 
Fico sabendo que o Barriga chama-se assim por andar como personagem de um programa de humor da televisão e, também, por ter levado uma facada na barriga dada pelo Colorau (que está no Centro de Recuperação de Menores, o CRM) (2).

Na Feira do Rato, vi mais meninas do que na praça: Cícera, Raimunda, Carla... Conheço o Mário; comentam que ele foi líder no assassinato de Bambu, morto no início do ano na casa velha ao lado da Igreja dos Martírios. Isso não é assunto corrente e nem denunciado. Mário é liderança respeitada; já é adulto. Não rouba diretamente. Um adulto furtando nos pontos de ônibus e ruas do centro comercial é fato que chama atenção, sendo mais próprio para os menores que correm em pinote ao arrancarem uma bolsa, dinheiro ou vale-transporte. Falam que funciona como líder, inclusive no recrutamento de outros meninos menores, não correndo assim os riscos das penalidades legais, por não ficar tão vulnerável.

Noto que na Feira do Rato, os meninos têm vivência maior pela relação com os feirantes e freqüentadores do local. Essas relações passam pelo roubo (a Feira é conhecida por comercializar produtos de roubo); a proteção que passa pela amizade, o sexo e as drogas. Também por ser o ambiente, feira-mercado, lugar onde alguns barracos funcionam como motel na prostituição de meninas e mulheres.

Falam que o Bruno foi preso e está desaparecido há vários dias; foi visto circulando no carro da polícia, provavelmente forçado a identificar os outros meninos que furtam na rua. Foi solto após alguns dias circulando com a polícia. Ainda hoje, por volta de dez horas da manhã, a polícia parou o camburão na feira e mandou que ele entrasse. Bruno entrou chorando. Também entraram João e Raimundo; foram algemados na carroceria da caminhonete. Cena constrangedora, deprimente e ilegal. Cícera - sua namorada - e Raimunda choram muito, pois Bruno (o único adolescente) foi solto nesta manhã para logo ser preso. Pra falar a verdade, só deu tempo pra ele chegar na feira, não cometendo nenhuma infração. Soubemos que foi encaminhado à Delegacia de Roubos e Furtos e não à da Criança e do Adolescente, ou a "de Menor". Então a situação é essa: ele está preso novamente, logos após ter sido liberado, sem flagrante, sendo recolhido para uma Delegacia não-especializada e imprópria. Consideramos pressão psicológica e abuso de autoridade.

Observo as meninas que vi marcadas nos braços por cortes longos e regulares; soube serem elas mesmas as responsáveis pela maioria dessas marcas. Os ferimentos são feitos em situações de depressão, alucinação por drogas ou raiva.

Manoel, um garoto de 12 anos, vem ao Centro pedir para o educador cortar seu cabelo, mas não estamos com a tesoura própria. Manoel busca uma tesoura de papel e passa, ele mesmo, a cortar o cabelo. Com raiva de nós, por estar com o corte todo falhado, começa a fazer terrorismo com os piolhos que vão caindo, ameaçando coloca-los em nós, e nos persegue em correria com seus piolhos na mão. Não satisfeito, sobe ao telhado ameaçando entrar dentro da caixa d'água. 
É um alvoroço, mas tudo acaba bem, até com algumas boas risadas. Observo ser comum no comportamento deles essas formas de chamar atenção. Agem conosco como agem com os colegas da rua.

25.11.99 - Quinta-Feira. Na Feira do Rato, conheci Paula (a Chefona) e Joana (a Arranca). Elas, apesar de adultas e maior experiência, não se diferenciam muito das outras meninas em situação de rua; isso, pelo comportamento, modo de vida, linguagem e por estarem habitualmente convivendo no mesmo espaço. Também, pelo fato de não crescerem tanto, devido, inclusive, ao uso da cola por anos seguidos e à má alimentação. A Arranca está com a boca arrebentada; soubemos que apanhou na Feira. Ainda não conheço seu rosto, pois nos horários da manhã, quando freqüento a Feira, ela está sempre deitada, completamente coberta por um lençol em frente ao Palácio do Trabalhador, local de abrigo de muitos dos meninos e meninas que vivem na região do mercado. Soube que Joana é anêmica. É um referencial de informações na feira. Sabe de tudo o que acontece e com quem; é relativamente respeitada no espaço, acho que por antigüidade, também a chamam de Galega.

29.11.99 - Segunda-Feira. Logo cedo, ainda no Centro, lemos jornal afirmando que a venda de cola de sapateiro a crianças e adolescentes estava acabada, sendo a venda a adultos fortemente fiscalizada pela polícia. $\mathrm{Na}$ ida à praça, vimos cerca de vinte meninos em reunião, distribuindo cerca de dois litros de cola, chegando inclusive a brigarem entre si. Vado e Língua brigavam. Mesmo sangrando, o Língua continuou a seguir o grupo que foi em direção ao centro comercial. de Maceió'. Neste trabalho, ela comenta pormenorizadamente o dasaparecimento de um menor que se insinua neste texto: o Labirinto. Tudo se deu em circunstância até hoje não esclarecida oficialmente, havendo, contudo, a possibilidade de o inquérito ser reaberto.

Na realidade, o Diário de Cláudia vai bem mais além do que Maceió; passa fronteiras e ele poderia ter sido escrito nas mais diversas cidades brasileiras em que a composição urbana pode ser entendida como um gráfico da miserabilidade. Menores que estão aqui nas ruas de Maceió, estão nas mais diversas ruas das mais diversas cidades.

Por outro lado, é uma historiografia contundente e fundada em um depoimento prestado enquanto o tempo anda, destacando aquilo que se tornou mero componente de cenário: o drama humano. Nisso, reside a aproximação entre a história e a vida e realizá-la foi a primeira intenção do texto pois o menino de rua deixa de ser uma categoria a mais nas análises para sofrer, amar, chorar e morrer. É tanta a aproximação deste tipo de história com a vida, que mais parece ficção, mais parece com um autor correndo livre sobre as malhas do real e reinventando o mundo. Contudo, não é assim: é um depoimento com a marca do autor, mas imerso no real de quem faz das ruas um local de morada e, portanto, crú.

Luiz Sávio de Almeida, antropólogo, é professor da Universidade Federal de Alagoas . 
30.11.99 - Terça-Feira. Hoje fiz minha primeira visita domiciliar. Saímos até a casa de Tiago, 16 anos. Ele é um adolescente que depois de ter sido reencaminhado à sua casa, voltou para a rua. Fomos fazer o acompanhamento. Ele, enquanto permaneceu em casa, teve boas notas e passou a vender amendoim com carrinho ambulante na porta de escolas. A mãe e o padrasto moram no bairro do Benedito Bentes. Dona Madalena não estava em casa; viajava. Seu Araújo nos recebeu. A casa é pobre, mas possui uma estrutura razoável para viver. Garantiria, em tese, algum apoio em alternativa à rua. $\mathrm{O}$ período de viagem de Dona Madalena corresponde ao período em que Tiago encontra-se de retorno à rua, na Praça dos Martírios. Percebi aborrecimento mútuo causado entre padrasto, o filho e a mãe de Tiago. Tiago não quer seguir as regras dadas pelo padrasto e a escola.

Também percebo imediatismo na conversa de Seu Araújo; parece não perceber a relação familiar quebrada, responsabilizando Tiago por toda a situação de risco que está vivendo. A fala de Seu Araújo segue para exemplos pessoais de como se criou e como acha que Tiago deveria fazer. Seus modelos de educação são fixos em sua própria história de vida. Soubemos que Tiago tem um irmão em São Paulo. Sugeri ao padrasto que pedisse a esse irmão a escrita de uma carta a Tiago. Nós leríamos para o adolescente e veríamos que resultados surgiriam daí. Essa sugestão foi posta como alternativa à situação de aborrecimento geral da família. Percebo uma espécie de competição entre Seu Araújo e Tiago, como se o padrasto, por não aceitar o garoto, pressionasse Dona Madalena a escolher, com a desculpa de ser o adolescente culpado pelo estado de coisas. As palavras de Seu Araújo sobre Tiago: “Dá trabalho e não quer seguir a ordem". É importante observar também que Seu Araújo não trabalha, sendo a renda familiar toda vinda da aposentadoria de Dona Madalena.

10.1.2000 - Sábado. A filhinha de Vado foi morta. Corre a notícia de que foi espancada pelo padrasto e com o aparente silêncio da mãe. Ela, a mãe, continua com o marido. A menina tinha quatro ou cinco anos, Vado não sabe precisar. Vivia na rua com a mãe e o padrasto, foi enterrada como indigente já que não era registrada. Ninguém sabe onde foi enterrada. Tudo aconteceu no final de semana, mas somente soubemos na segunda, ou seja ficamos sabendo só o que foi passado e repassado e o que o próprio Vado nos contou. Ele disse ter pegado a menina, há algum tempo atrás e posto na casa do seu tio, mas a mãe foi buscá-la e ela voltou a viver na rua.

A tragédia quase constante que é a rua desmerece qualquer absurdo. Tudo acontece tão rapidamente e justiça e legalidade são valores diferentes no calçamento. Neste contexto, os fatos vivenciados irão obedecer a uma lógica própria.

Sobre Vado: é um adolescente de 17 anos, criado até certa idade, quando ainda pequeno, pelo avô. Quando o avô morreu deixou seus bens para o neto. Mas Vado nunca usufruiu de nada; diz ter sido roubado pela família que nunca 
deu conta de nada a ele. Depois de sua vinda do interior para Maceió, em fuga de casa, foi criado por um travesti, hoje já morto. Vado é um dos adolescentes mais acessíveis e participantes das atividades e possui muito boa relação com todos os educadores. Cheira cola habitualmente e pra sobreviver...

26.1.2000 - Quinta-Feira. Na ida à rua vimos policiais a paisana, os chamados "homens da cola". Eles recolhiam a cola de todos os meninos da Praça dos Martírios. Vinham, se aproximavam e tomavam os cumbucos, colocando-os em uma sacola plástica. Davam um pequeno carão nos meninos e saíam. Para alguns não diziam nada. Eles aparecem de vez em quando e não sabemos por que vêm a paisana. Não sabemos se fazem isso por conta própria. Eles nos observavam e nada diziam conosco, também não interferimos. Aos meninos restava apenas olharem-se lamentando ou tirando graça um com a cara do outro. Os que conseguiram estar longe escondendo a cola por baixo da roupa, vinham depois cheios de poder por estarem ainda "de cima" (gíria usada referindo-se a quem está com a droga). Alguns policiais militares dentro de uma viatura estacionada ao lado da Igreja, observavam todo o movimento sem reações.

3.2.2000 - Quinta-Feira. Na Praça dos Martírios, encontramos Cabuloso, 10 anos, debaixo de sol, deitado no chão, dormindo dentro do chafariz vazio, com a barriga cortada pela grade da Igreja de onde tentou pular e acabou ficando preso até sair e rasgar a barriga. O corte é grande. Fomos eu e Átila num primeiro momento para tentarmos levá-lo ao Hospital de Pronto Socorro, mas ele não queria de modo algum sair de onde estava. Esperneava e fazia birra, apesar de dizer que o corte doía. Foi depois que Átila comprou um caldo de cana com pastel que ele sentou. Já conversávamos, e daí ficou mais fácil levá-lo até ao Centro de Apoio para esperar um táxi que nos levaria ao hospital.

Enquanto tentávamos convencê-lo a ir conosco, as pessoas que passavam nos abordavam perguntando o que havia acontecido. Outros condoídos, chamavam-no de "bichinho", e outros paravam para olhar com expressão de sarcasmo saindo logo em seguida. Uma mulher disse que éramos filhos de Deus por estarmos com o menino naquele momento, porém ninguém parou em atenção para oferecer ajuda. Foi um ferimento sério, exigindo cuidados, inclusive higiene.

10.2.2000 - Quinta-Feira. No final da manhã, o menino Marcelinho (sete anos) aparece no Centro; ele já veio - em outra manhã - para o banho. Hoje chegou apresentando-se como Paulina. Estava vestido com roupas femininas, assumindo esse papel também no modo como falava e andava. Começaram a surgir alguns rumores de que ele estaria indo à praia fazer programa durante a noite. Conversarmos com os travestis Gildo e Gusmão, freqüentadores do Centro. Eles negaram, dizendo saber da irresponsabilidade que isso representava. Sabiam inclusive que poderiam ser presos. Falaram que se isso acontecia era por conta do garoto. Ficamos de investigar. 
Alguns meninos que viram Marcelinho agindo como Paulina, disseram têlo visto namorando com o Cabuloso, mas este negou ao ouvir o comentário dizendo: “Ôxe, eu não! Óia! Eu não, eu não namoro com viado não." Cambito comenta na praça, em tom de brincadeira e cinismo, ter transado com Batata. Essas informações chegam a nós geralmente em tons de brincadeira e falação, sem podermos saber exatamente o que acontece. Penso até onde podemos interferir, a orientação deve acontecer, enquanto o uso do preservativo e escolhas que envolvam ao menos um pouco de carinho nas relações, mas nesses casos onde as informações chegam desse modo, e geralmente são negadas, fica bem difícil entrar nesse universo.

A história do menino Marcelinho é algo mais explícito, mas a nossa interferência, acredito, deve corresponder exatamente até onde alcançamos. São indivíduos que respondem ao que está posto, então se a noite apresentar situações tais que ao nosso ver são absurdas, para eles são experiências próprias, as únicas que possuem diante dessa relativa liberdade que a eles se apresenta. Temo tecer julgamentos. Preocupo-me em respeitá-los. Então o trabalho educativo segue no sentido de orientação, mas pergunto-me em que espaço fica localizada e diluída esta tal orientação diante desse todo da rua que está posto dia após dia e em tantas noites?

13.3.2000 - Segunda-Feira. Hoje tumulto, pela manhã, na Feira do Rato. Boneca se contorcia no chão com ardência na vagina. Ela estava em tratamento ginecológico, mas por não ter feito os exames e tomado os cuidados o problema piorou. Não quis ir ao médico conosco, dizendo que era longe, mas ao mesmo tempo em que dizia isso já combinava com Cícera a ida a algum lugar, com a cola. Ela já possui uma ficha diagnóstico em um posto de saúde, mas não quis ir conosco, ficou marcando para depois, deixamos a escolha na sua mão. Observo Geno na máquina caça-níqueis. Permaneceu durante muito tempo perdendo e ganhando moedas, a máquina está disposta no meio da feira, com uso aberto a todos inclusive aos menores de idade.

14.3.2000 - Terça-Feira. Mais uma vez, logo cedo, encontro na feira as meninas envolvidas em suas relações com os feirantes. Elas freqüentam e se situam mais no ponto do corredor principal, onde ficam as barracas de Seu Doda, uma espécie de eletrônica. Os meninos também ficam por ali, mas preferem o início do primeiro corredor, mais perto da linha férrea. Esta ponta atrai pela presença dos televisores à venda e sempre ligados. Lá eles ficam no chão, sentados, com ou sem a cola, atentos a ver os desenhos animados.

Como disse, as meninas se situam mais na barraca do Seu Doda, ponto central. Não sei ainda exatamente por que. Percebo que ele é muito simpático, inclusive com o trabalho dos educadores. Ele tem relação estreita com as meninas. Sobre Boneca, falou que deveríamos levá-la a força para que ficasse boa logo; segundo ele, com elas tinha que ser assim mesmo. 
Cerca de 15 policiais militares faziam uma batida pela feira. Boneca ia sendo levada pelo braço. Foi detida por ter pego do chão uma carteira jogada e vazia, produto de roubo, uma "desova" . Ao mostrar ao policial a carteira foi perguntada estupidamente pelo policial de quem era e o que fazia com ela. Boneca começou a gritar com o policial, a chamar a atenção de todos, um tanto de propósito, em desrespeito aos mesmos, segundo as outras meninas que contaram o fato. Ela foi levada para o interior do Palácio do Trabalhador e lá permaneceu gritando sob os olhos de todos que criticavam e teciam comentários a respeito dela.

Ao tentarmos ver o que acontecia fomos barrados pelos policiais. Estes pediram que nos retirássemos, pois nós “ dos direitos humanos” não sabíamos quem eram essas meninas. Disse que elas se cortavam e colocavam a culpa neles. Também falou não poder deixar uma criança desrespeitar sua farda. Falou em "Lei Fleury" e mais algumas coisas que não escutamos, pois eles pediram que nos retirássemos, pois não estavam maltratando ninguém. Ela foi encaminhada para a Delegacia da Criança e do Adolescente.

15.3.2000 - Quarta-Feira. Logo cedo, a feira, quase sempre está esvaziada de meninos, quando chegam é normalmente com a cola e em grupo, por volta de 9h30. Antes disso, é mais comum ver as garotas. Caçola nos observa longamente e pergunta se por acaso nós viramos detetives. Ri e sai. Um senhor, vendedor ambulante de relógios, que circula pela feira, ao observar uns meninos passado por ele, comenta com o colega, também ambulante, que quem ousasse rouba-lo seria morto. Um garoto novo chamado Marquinhos é testado pelo grupo. Os outros ficam empurrando, tiram sua camisa, riem, chacotam, correm atrás dele pela feira em brincadeiras provocativas. O teste é de paciência.

Quando vemos os meninos com a cola "morrendo", ou melhor dizendo, perdendo o efeito, sabemos que eles já estão se movimentando para compra de mais. A "risca", equivalente a medida de um dedo de cola na garrafinha, ou cumbuco, custa R \$ 1,00.

16.3.2000 - Quinta-Feira. A notícia do sequestro de José Heleno (16 anos), o Labirinto, é tema central. Três homens num carro preto, com vidros fumê e portando armas de fogo, pararam o grupo de quatro meninos, nas imediações da Praça Sininbú, mandando Labirinto entrar no carro dizendo para os outros: "Vocês pensam que ainda vão ver ele? Vocês não vão ver ele mais não!" Contam ser várias histórias. Alguns dizem que teriam sido policiais contratados por comerciantes para dar cabo dele, pois eram freqüentes os seus furtos na porta de estabele-cimentos. Teria sido também vingança de alguém parente de uma mulher grávida a qual ele roubou e que passou mal perdendo o filho. A segunda versão é corrente dos boatos da rua.

Observo Geno com roupas novas. Ele diz ter comprado. Às vezes o vejo na máquina caça-níqueis. Também já o vi distribuindo a cola aos outros. Acredito 
ser a Lúcia uma das adultas responsáveis pela compra da lata, daí os menores distribuem, o dinheiro deve ser dividido.

Em observação ao "rolé" - andar em grupo para roubar - nas ruas do comércio, observo Cabuloso, 11 anos, andando com Casé, 18 anos. Este, com o braço quebrado, dava instruções ao menino para os furtos nos aglomerados de pontos de ônibus. Cabuloso entrava no tumulto do embarque, como é pequeno, consegue roubar facilmente. Casé observava de longe, esperando, mas durante o tempo em que observei o menino nada conseguiu. O rolé acontece mais nos horários de saída do expediente. Vai dentro das 11 às duas e depois na saída da noite.

21.3.2000 - Terça-Feira. Na rua o assunto é o sequestro do Labirinto. É feito pelos educadores panfletagem sobre o caso no sentido de dar conhecimento à população sobre o que aconteceu. Algumas pessoas ao receberem, dizem saber quem é o menino; outras perguntam, algumas só opinam, a maioria não dá atenção.

Na Praça Deodoro, João diz ter visto Bode, Romão e Geno terem sido colocados num carro. Disse não saber quem fez isso. Entre outras coisas, ele disse dar dinheiro, vez ou outra à polícia para ser liberado. Calango pergunta se ninguém achou o Labirinto ainda. Pergunta se ele está morto. Entre outras discussões acerca da violência, pergunto a ele onde é mais seguro dormir a noite, já que estão sob esse clima de medo, e ele diz não existir esse lugar na rua.

29.3.2000 - Quarta-Feira. Cumbuco diz que bate em Mila porque ela rouba suas roupas e seu dinheiro enquanto dorme. Questiono entre outras coisas se ele gosta dela. Ele responde que sim. Depois que Cumbuco sai, Mila diz ter ele, quatro litros de cola para vender, e pede para eu não falar nada.

Converso com Geno sobre a possibilidade de irmos o mais rápido possível ver o seu problema de saúde, ele adia sempre quando marcamos. Está com alguma doença sexualmente transmissível e brinca dizendo: “ A cola é que não deixa ir". Também fala sobre um episódio acontecido dias antes: “Tia, desculpe por aquele dia eu ter sido ruim com você viu?”

$\mathrm{O}$ adolescente Tota, um dos meninos que viu o sequestro do Labirinto, veio correndo em direção ao Centro, fugindo do carro que descia a ladeira com os dois homens que ele diz terem pego José Heleno, o Labirinto. Estava a bater aguardando para entrar no Centro. No momento em que Tota chegou pedindo socorro, a porta foi aberta por outro educador. Tota contou ter recebido recado de um taxista que dizia estarem querendo lhe pegar. Logo depois veio o carro perseguindo-o pela praça. A educadora também esteve exposta. Na verdade, todos os que se envolveram com o caso estão preocupados.

8.5.2000 - Segunda-Feira. A praça está ocupada pelo Movimento dos Sem Terra. Isso alterou um pouco a rotina dos meninos por lá. Os meninos Pedro, 
Paulo e Cambito foram levados a delegacia, na tarde anterior por fazerem guerra de confeitos na praça. Ele disseram hoje, já soltos, que os confeitos atingiram os policiais e por isso eles os levaram. Quando tento explicar a Cabito que isso não pode se repetir, que eles não podem sofrer esse tipo de coisa ele me interrompe e começa a cantar a oração de São Francisco de Assis. Falou que seria o cantor da banda e não quis mais falar sobre as agressões.

10.5.2000 - Quarta-Feira. O MST está levantando acampamento, sairão da Praça dos Martírios e voltarão aos assentamentos e ocupações de terra. A maioria dos meninos da praça e alguns da feira, dizem que irão com eles. Os próprios integrantes do movimento falaram que têm interesse em levá-los. Disseram que “pegam” um ou dois meninos de cada família. Esse interesse acontece porque as adesões encorpam a luta do movimento, além de serem os meninos mão- deobra em ajuda às famílias. Precisamos fazer também esse acompanhamento para evitar os excessos.

11.5.2000 - Quinta-Feira. Alguns meninos da praça realmente foram com o MST aos acampamentos. Cambito antes de ir falou só voltar após uns anos quando já tivesse arrumado tudo. Ele diz não gostar de estar em casa, não consegue lá permanecer, está sempre a fugir.

Paulo, 13 anos, diz que quer seu registro de nascimento para poder voltar a casa da avó. Ele diferente de Pedro, 12 anos, seu irmão é aceito pela avó em casa. Pedro era um doce até a morte de sua mãe, por uma cirrose hepática, no meio do ano passado. Era alcóolatra, passava longos períodos sumida e em retorno colocava os meninos na rua a esmolar para ela. No período da morte de sua mãe, Pedro teve uma overdose causada por solvente. Passou longo período internado no Hospital Universitário, onde bastante agressivo quebrou janelas. Mas depois desenvolveu uma relação estreita com as enfermeiras de lá, às quais sempre faz referência e pede para ir visitar. Numa tentativa de ficar em casa, Paulo foi retirado de lá por Pedro mediante escândalos. Pedro não fica na rua só e não consegue permanecer na casa da avó que diz não o querer. Num primeiro momento, Paulo parece ser mais doce que o irmão, que é muito agressivo. Apesar de eu já ter sido agredida e xingada por ele, acredito na minha futura aproximação com o mesmo.

15.5.2000 - Segunda-Feira. A atividade na rua é a coleta de sucata para oficina de construção de instrumentos musicais. Encontramos Cabuloso, chapadíssimo, sempre brincalhão dizendo que antes da atividade precisa ir tomar banho no Centro, pois passou a noite perambulando com os outros e ainda não dormiu. Pedro está junto, mas chateado, nada quer, só xinga. Dois senhores riem das atitudes de Cabuloso que entre coisas engraçadas diz: " Nenhum policial vai ter minha cabeça não!" Está muito drogado, além de cansado. Achei mesmo difícil que quisesse estar na atividade musical. Combinamos de nos encontrarmos na 
feira para coletar a sucata depois que descansasse. Eles vão ao Centro para o banho. Paulo e Batata foram ao bairro do Joaquim Leão para comprar cola, soubemos.

Na feira encontramos a Caçola e propomos a atividade, ela concorda. A pego pela cintura, carregando-a em brincadeira. Ela faz charme, mas vai. O feirante brinca com a situação. Catamos de tudo: garrafas, latas, raios de bicicleta, ferros, madeira. Quem estivesse pegando mais material se gabava exibindo o conseguido. Na Praça Deodoro paramos para o picolé. Conversamos mais sobre as possibilidades para o seu irmão. Caçola é divertida. Traz conosco o material até ao Centro e nos ajuda a limpar e arrumar tudo. Diz que quer estar nas atividades, nos ensaios, mas praticamente não vem.

No Centro, Cabuloso já descansado e recuperado, ajuda o educador a arrumar a sala de música. Ele foi o único dos pequenos que ensaiou hoje. Batata tentou ficar, mas Pedro depois de me bater e xingar saiu arrastando o colega que já estava ensaiando. Brincava com uma cobra de pelúcia, mas logo tentou rasgá-la aborrecido. Saiu arrastando Batata. Entre todos, o único que saiu sem banho foi Pedro. Paulo cuidou de seu machucado conosco.

24.5.2000 - Quarta-Feira. Cambito ficou conosco na atividade de coleta. Está de volta às ruas há uma semana depois de ter passado uma semana em casa. E foi para casa porque sua mãe o buscou na praça, na tarde em que o MST estava retornando aos acampamentos. Ela impediu que ele seguisse o grupo e o levou para casa, surrando-o ao chegar. Perguntou a nós quando seria a próxima reunião dos pais, e disse que no dia sairia da praça e das redondezas para não ser achado por ela. Sua mãe mora no Complexo Humberto Mendes (3), ao lado da Cidade de Menores. Numa casa pequena.

25.5.2000 - Quinta-Feira. Encontro Mariana, sete anos, no ponto de ônibus e ela me diz que seu irmão, o Galego, tinha sido morto por um grupo ao qual chamou de "cheira cola". Disse que já fazia duas semanas do acontecido. Falou o nome de um garoto do grupo da praça. Pergunto por sua mãe e ela diz está viajando. Falou que estava na casa de uma tia. Uma moça que nos observava disse que a menina era falsa, que me abraçava para depois roubar. Falava para eu não confiar, que eu só estava a dar conversa pra menina por não conhecer. Mariana se aborreceu enquanto eu conversava com a moça explicando-lhe que conhecia a garota, comentando suas observações.

A menina falou desaforos para a moça. Antes de sair, tirou uma pulseirinha do seu braço colocando-a no meu. Disse em tom ríspido que se não me visse com a pulseira assim que nos víssemos novamente, eu veria só uma coisa e saiu brincando. Eu fico sem saber o que fazer, ao mesmo tempo em que estou assustada com a notícia que me deu, não compreendo o modo de agir da menina, que á muito confuso e instável. Uma história improvável, pois se acontecida a duas semanas atrás, naturalmente saberíamos, ou haveria um corpo. Necessário apurar. 


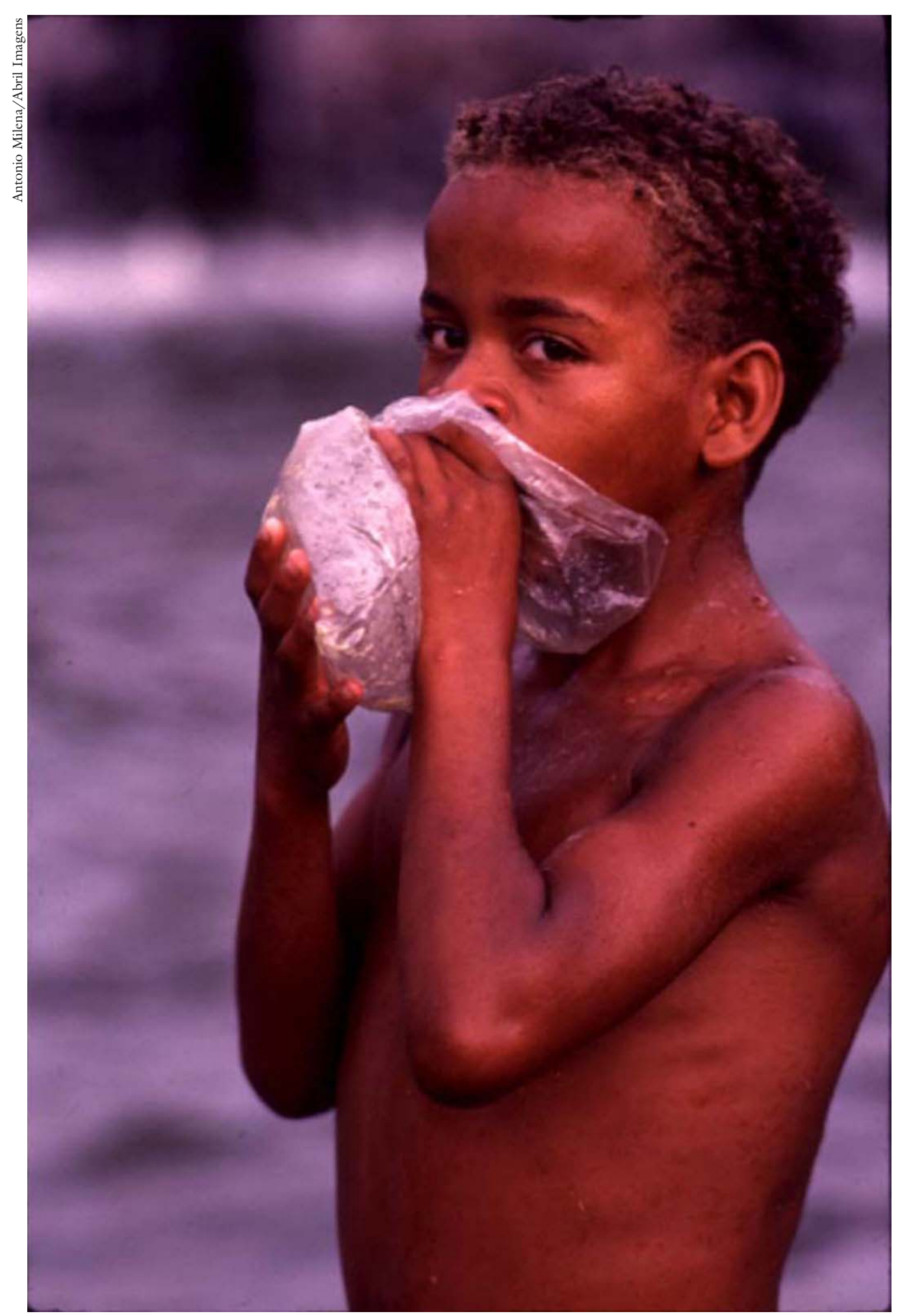

Ela me diz que sen irmão, o Galego, tinha sido morto por um grupo ao qual chamon de "cheira cola". 
29.5.2000 - Segunda-Feira. Na Praça Deodoro conhecemos Luiz, 12 anos, está sendo cuidado pelo travesti Anete. Este, disse que antes ele era muito sujo e ficava muito solto na rua. Luiz estava com a cola quase morta, ou seja, sem efeito. Quando eu pergunto se a cola dele está morta, ele me olha com desconfiança e pergunta como é que eu posso saber disso; pergunta se eu cheiro cola. Explico-lhe que não, que não acho legal, mas por conviver com todos acabei sabendo diferenciar pelo cheiro e aparência. Ele então começa chamar a cola de mel, dizendo que é uma droga do diabo. Mexe a cola com um palito de churrasquinho tentando ativar o cheiro e começa a aspirá-la na nossa frente. Conversamos sobre o fato de não usarmos cola, de queremos estar ali conversando com ele, mas isso não poderia acontecer caso ficasse mais chapado. Também falamos sobre o fato de não ser legal a droga e que poderíamos ter problemas com a polícia, já que essa não gostava muito de nós, por fazermos trabalhos com os meninos que estão na rua. Por fim, dissemos que na atividade nós sempre pedíamos para os meninos guardarem a cola. E muitos já faziam por iniciativa própria.

Ele contou que saiu de casa porque apanhava da mãe com fios de borracha, fios elétricos velhos, e nos mostrou as marcas pelo corpo, uma no pescoço, quase rosto. Disse que ela mora no bairro do Feitosa, tem mais dois filhos, sendo um policial militar com 25 anos. Disse que iria ao Centro ver as atividades. Antes de sairmos fez alguns passos de capoeira.

12.6.2000 - Segunda-Feira. É dia de troca de guarda no Palácio do Governo, uma solenidade militar, e chama a nossa atenção a atitude de Sérgio, por estar cheirando cola em meio às bandeiras hasteadas, bem perto dos policiais. Esse dia chama a atenção dos meninos por ser o único em que aparecem os ônibus com turistas em city tour. Eles aproveitam para esmolar, a maioria não recebe nada. Mesmo assim, insistem em conversar com os visitantes, sendo muitas vezes engraçados. Soubemos estar bem o Galego, irmão de Mariana. Ela havia dito ter sido ele assassinado por outros garotos no mês de maio. Foi uma fantasia dela, pois ao comentar com a mesma sobre o fato ela disse nunca ter falado isso.

6.7.2000 - Quinta-Feira. Sei do caso de Gerônimo. Está na rua, porque há quatro anos pediu uma bicicleta emprestada de um vizinho e disse ter sido roubado por um grupo que não gostava dele. Ficou com medo de voltar para contar o fato e se explicar a quem lhe emprestou. Essa pessoa, com o sumiço de Gerônimo, passou a achar ter sido ele quem roubou. Está na rua desde então e conta não mais poder ir ao bairro onde mora sua mãe. O educador Átila, a quem Gerônimo contou o fato, estuda a possibilidade de interferir diretamente com essa pessoa, o dono da bicicleta, na tentativa de ao menos colocá-los juntos para conversar sem maiores confusões. Gerônimo contou isso ao educador na tarde anterior enquanto dizia, deprimido na praça, querer se matar por não aguentar mais viver na rua. 
Uma interferência positiva de Átila, nessa mesma manhã, foi quando se dispôs a conversar com o moço que queria "pegar" o Neno. Havia este, quebrado o vidro da janela dessa pessoa, por acidente, numa brincadeira, que fazia com os outros meninos ao lado dessa casa. Depois das explicações mediadas pelo educador o caso se resolveu.

17.7.2000. O pai de Fê veio buscá-lo na rua. Fê só tomou sua benção e foi embora. Está novamente na rua devido ao fato da esposa de seu irmão não o querer mais em sua casa. Desde que foi para a casa do irmão, não pára por lá chegando a dormir na rua várias noites. A cheirar cola, aparece por lá quando bem quer. Ela se incomodou com isso, dizendo que ele não queria mudar. Desde então não o aceita mais. Devido ao uso da cola a dentista não quis mais atendê-lo. A recomendação dada foi para ele não fazer uso dela antes de ir ao consultório. Ele não cumpria. A dentista resolveu parar o tratamento até que ele resolvesse fazer o recomendado. Fê está com os dentes bastante estragados e sentindo dores. Está matriculado no CAIC do seu bairro, o Tabuleiro dos Martins.

20.7.2000 - Quinta-Feira. Cabuloso ameçou comprar um cigarro a varejo, reafirmamos a regra do não uso de drogas em atividade conosco. Ele fez piada, fazendo que ia fumar, mas logo jogou fora ao lembrar a história de sua mãe contando-a para nós:"Minha mãe era bem gorda assim... aí ela ficou bem magra. Ela fumava muito. Ela ficou doente. Quando foi um dia... como é que chama aquele negócio pra tampar mosquito? É! É mosquiteiro mesmo. E levantei o mosquiteiro assim, e ela tava lá com a boca cheia de formiga. Eu olhei assim, fui pra um cantinho assim que tinha no quarto. Chorei lá, fiquei chorando. Foi quando meu tio veio e olhou ela." A partir dessa história conversamos mais sobre quando vivia em Satuba, mas tudo acabou sendo muito cortado, pois a essa altura já estávamos dentro do ônibus cheio.

Lenilton está passando de família em família no acampamento do MST, em Maragogi. Lá as famílias já têm muitos filhos. Foi dito que ele estava cheirando cola por lá. Isso criou um mal estar entre as famílias. Um dos líderes falou estar o movimento aberto aos meninos da rua, mas lá, porém não seria permitido esse tipo de atitude, por causar transtornos junto aos pais que também têm filhos adolescentes. Eles temem a dispersão e o uso das drogas. Lenilton disse aos educadores, que foram fazer o acompanhamento, não querer voltar a Maceió.

10.8.2000 - Quinta-Feira. Logo cedo ao irmos à praça, vemos Misael, com a cola na boca. Ele se constrange e depois de breve conversa atira a cola longe. Conversamos um pouco mais, amenidades, e ele vem conosco ao ensaio da atividade musical, também grava conosco uma história contada por seu tio e que aprendeu, é a história do Bicho Corredor.

Lael está na UTI do Hospital de Pronto Socorro, depois de ter se acidentado na tarde do dia anterior. Ele descia a Ladeira dos Martírios montado numa 
bicicleta sem freios, quando então se chocou com um ônibus que passava. $\mathrm{O}$ ônibus passou depois que o sinal abriu para os carros. Ele está inconsciente e perdeu muito sangue. Precisa de doadores, decido ir doar. Átila tem anemia e não pode. Precisamos arrumar mais pessoas. No Hemoal encontro o seu tio que também foi doar sangue para o sobrinho, a mãe do menino não apareceu no hospital. Pergunto se ela foi avisada e o tio do garoto indignado comenta sobre o fato de ela ser negligente com os meninos que estão todos na rua. $\mathrm{Na}$ semana passada quem quase rachou a cabeça numa queda ao correr cedo da manhã quebrando as lâmpadas dos postes do comércio, foi Lailton, seu irmão menor, ele ainda está com a cabeça enfaixada. Eles estão em fase de conquista para possivelmente ir ao Projeto Horta (4). Ao doar sangue não passo muito bem, uma tontura misturada com emoção e também indignação. Lembro das palavras do tio de Lael, em comentário a aparência dele na UTI: "Como é que pode uma criança numa situação dessas?"

22.8.2000 - Segunda-Feira. A prisão de Tiago e Cambito, logo cedo, deuse porque Tiago tentava roubar uma cachorrinha de um menino novo na praça, causando bate boca e confusão. A polícia ia passando, viu tudo e desceu para saber o que havia acontecido. Ao saber do ocorrido, colocou Tiago na viatura. Este, gritava ameaçando o menino. Disse que o pegaria quando retornasse. Acredito ter sido o grupo de meninos reunidos e a situação da cola quem motivou a parada da viatura. Cambito que também tumultuava em redor da situação estava com uma garrafa grande de refrigerante contendo cola. O policial que já tinha visto antes perguntou onde ele a havia escondido e Cambito que estava com ela por baixo da roupa passou a fazer piada com o guarda dizendo não ter nada. Esquivando-se a cada momento da revista, confundiu o homem que não entendia onde afinal ele teria escondido a cola. Ao finalmente achá-la, o policial bastante aborrecido levou Cambito, que em risadas foi colocado na viatura junto com Tiago. Foram encaminhados a Delegacia Especialiada.

Gerônimo esfaqueou Cumbuco, na tarde do dia anterior, depois de confusão causada por Mila. Esta, criou uma situação de desafeto entre os dois. Ela é namorada de Cumbuco, mas estão sempre a brigar. Gerônimo era amigo de Cumbuco e causou espanto a todos o fato. Cumbuco foi hospitalizado e está refugiado na Cidade de Menores. Gerônimo sumiu porque agora Nel, o primo de Cumbuco quer acertar as contas com ele. Os dois são muito populares na rua.

Todos os meninos do grupo reunido ao lado da Igreja estavam com cola nova, visivelmente muito drogados. Decidimos não ir lá, por não vermos condições de conversa e atividade, ficamos por perto para o caso de quererem se aproximar. Fê aproximou-se, indignado cobrava atenção. Perguntou porque não estávamos falando com ele. Ele percebeu, e isso foi bom. Resolvemos deixar com que ele nos procurasse porque nas últimas vezes em que o procuramos ele foi agressivo com suas piadas e insinuações. Desde que retornou a rua, depois 
de o encaminharmos para o Centro, passou a nos evitar, por vezes era agressivo e desagradável. Explicamos que não o ignoramos, mas também não queríamos que ficasse a chacotar conosco, pois não era essa a relação que desejávamos. Falamos de nossa preocupação com ele, de suas pendências com a dentista e a escola em que o matriculamos. Também o fato de estar em retorno a cola, dos 16 anos que fez, da abertura que seu irmão deu ao concordar que morasse em sua casa, já que sua relação com o pai estava tão quebrada. Ainda foi colocado o fato de a mendicância para ele - essa atividade favorece aos pequenos - com o tempo já não funcionaria mais, tendo ele que arrumar outras formas de sobreviver. Refletimos sobre o que escolheria. Falamos de instituições que poderiam atendê-lo enquanto abrigo. Porém, reforçamos o fato de em ele tendo casa, e pessoas que de alguma forma o queriam e com os encaminhamentos já dados, ele estaria a desperdiçar e também de alguma forma tirar o lugar em instituições, de outros meninos que não possuíam suas condições. Ele quer ir ao Projeto Horta, mas assim como outras instituições, é destinado um número limitado de vagas ao nosso Projeto, dando eles inclusive preferência às situações de maior risco e vulnerabilidade. Fê não se esforça para as coisas a que se propõe, responsabilizado sempre a todos por tudo o que não consegue realizar. Ainda hoje ele veio ao Centro tumultuando e dizendo mentiras a nosso respeito, agindo como criança em birra, de forma a nos chamar a atenção.

Tem um grupo novo de irmãos na praça, são duas meninas e um menino. Pedro está namorando com a maior. Cheiram cola no mesmo tubo e se abraçam. Quando brincamos com ele sobre o namoro, o mesmo põe o antebraço no rosto, a se esconder, com timidez e vergonha. O casal estava em harmonia e brincadeira, mas Átila contou-me estar Pedro e Bel, à tarde, correndo atrás da menina com pau e pedra para agredi-la.

23.8.2000 - Quarta-Feira. Fomos fazer o convite aos meninos para a ida ao Teatro de Arena, assistir as apresentações da Oficina Cultural, promovida pela Secretaria de Cultura, em promoção ao mês do folclore. Eu, dançaria o Coco de Roda, pois faço parte do Grupo de Tradições Folclóricas do Museu Théo Brandão, que entre outros grupos de folguedos e danças de bairro também se apresentariam. A oficina era direcionada a alunos de escolas e entidades de apoio que quisessem participar. Fomos a feira chamar aqueles que diante de nossas relações de atendimento quisessem participar. Lá, Geno e Gia, quiseram participar, mas acabaram não indo por não concordar em guardar a cola. Queriam escondê-la em baixo das roupas. Como não concordamos, queriam que guardássemos, alegando que com isso não estariam cheirando. Reafirmamos o fato de a cola não ser permitida em nossas atividades e que por ser ilegal não andaríamos portando a cola conosco. Eles decidiram não entrar. Foram então somente, Neno e Cabuloso. Foram ao Centro, tomaram banho e guardaram a cola na rua. No teatro durante a apresentação do grupo em que eu dançava via 
os dois rindo muito a fazer piada com o vestido que eu usava, mas depois eles passaram a cantar trechos das músicas que conheciam, integrando-se com o resto do público, a maioria de escolas. De longe via Cabuloso paquerando uma outra menina que sentava perto dele. Outros grupos se apresentaram com os Mestres de Reisado, Guerreiro, Baianas e Pastoril conversando com as crianças e também a ensinar passos.

Pedro está mais doce. Quando eu passava pela praça, ele que geralmente me destrata, gritou por mim "Galega!", rindo e perguntando envergonhado se eu tinha visto a garota que ele estava namorando no dia anterior. Num outro momento, ele dava cabeçadas leves no braço do educador Átila. Perguntei se era aquilo carinho ou agressão, ele sentou, riu timidamente e com a cabeça baixa falou ser carinho.

10.9.2000 - Domingo. A atividade de construção dos fantoches de sucata ficou à mercê do tempo chuvoso. Na praça ninguém estava. Na feira, o convite foi feito a Romão e Bel, estes aceitaram. Porém, no grupo que se aproximava, todos estavam com a cola, eles olharam para os demais e Geno disse: "Tem que ir sem cola e eu não vou não." Também o Bel: "Depois eu vou, depois eu faço." É importante colocar que eles têm desejo de trabalhar as atividades, mas quando é colocada a guarda da cola, muitos desistem.

Quando passamos pelo comércio encontramos Pedro e Batata na porta da Lotérica, abordando as pessoas que saiam com o troco dos pagamentos lá feitos. Os dois, com a cola, saíram da porta ao nos ver. Mas ao olharem novamente, viram que estávamos com um fantoche da peça "O Bicho Corredor", o velho com olhos de feijões. Logo se aproximaram. Pedro ao ver o boneco disse: "Por que você fez eu?" E o educador Átila disse: "Não, você é mais bonito." Já com o boneco na mão, Pedro passou a dizer que o boneco era seu. Não desgrudou mais. Na porta da lanchonete assistimos ao desenho animado Digimon. Eu disse que nunca tinha assistido antes e Batata passou a me explicar o desenho definindo as personagens a partir dos que eram do bem e do mal. Ao pedir que me dissesse o que era bem e mal ele se impacientou e chamou Pedro para andar. Os dois estão constantemente mau humorados, têm 12 e 14 anos.

11.9.2000 - Segunda-Feira. Encontramos mais meninos do que ontem. Todos gostaram dos fantoches que novamente levamos. Pedro novamente não desgrudou do velho com olhos de feijões e passou a brincar com ele, mexendo com as pessoas do pontos de ônibus, na janela do táxi, de modo doce, até encantado tal era sua forma de se movimentar e conversar com o boneco e as pessoas. Dessa vez todos quiseram guardar a cola fora do Centro para entrar e fazer os seus bonecos de sucata. Pedro não quis produzir dizendo que o seu já estava pronto, o velho com olhos de feijões e cabelo de linha, o vovô da peça. O boneco que ele confundiu com ele mesmo. É muito interessante isso, principalmente pelo fato de 
ele nunca querer participar de atividade nenhuma, ser rejeitado pela avó, sua única parente viva, estar constantemente resmungando e mau-humorado.

18.9.2000 - Segunda-Feira. Em atividade de construção de bonecos e personagens conheço Walli, 15 anos. Durante o trabalho conversamos. Ele diz: "Vai fazer um mês, eu já era do Projeto Horta. Passei sete anos na Horta. A minha mãe falou com a mulé pra ir quando eu fugi de casa. Ela fica dando neu quando bebe." Ele diz que gosta da mãe. "Eu fugi de lá, Terezinha me pegou aqui e eu vou lá. Fazia a segunda série na Horta. Eu não me interessava em estudar. Já fiz mecânica, artesanato, padaria, tudo lá. Logo que eu cheguei lá, eu fiquei varrendo. Porque quando eu ia pegar caju deixava eu de castigo. Eu comecei a cheirar cola quando minha mãe trabalhava lá na Ponta Verde aí os cheira cola, botaram eu pra cheirar, aí eu fui me acostumando. Eu gosto, mas eu não sou aviciado. Quando não tem dinheiro, aí rouba pra comprar, aí é aviciado. Eu vou arrumar um trabalho aí no comércio, eu vou trabalhar." Diz que pede para conseguir dinheiro. O episódio da cola aconteceu quando ele tinha sete anos. Walli fez um fantoche com o material de sucata, enquanto conversávamos. Um boneco de nome João, com nariz lilás, os olhos vermelhos e roupa de plástico azul. Walli diz: "Ele é da rua. Cheira cola, só não faz fumar maconha e nem roubar. Pede. Um dá, o outro não dá. Ele não sabe ler e nem escrever. João tem nove anos. Tá na rua. João é amarelo porque cheira cola. O olho vermelho foi um cisco.”

20.9.2000 - Quarta-Feira. Paulo continua a história do fantoche João, que Walli construiu na praça. "O João viu os pivetes jogando chimbra com o dinheiro da mãe dele. Só dele comprar carne. Aí, ele arrancou a bunda da avó dele que tava morta. Aí, quando foi no outro dia ela disse: João eu estou perto de seu quarto. João...!" Depois de continuar a história com esse trecho Paulo pergunta se Walli fez a avó do boneco João. Paulo tem como referencial familiar a sua avó. Esta o quer em casa, mas não ao seu irmão Pedro, o qual acusa de virar a cabeça de Paulo. Esses irmãos perderam a mãe há cerca de dois anos atrás quando esta morreu de cirrose hepática. Ela usava os dois meninos na esmola, inclusive para a compra de bebida alcoólica. Um tempo após a morte Pedro teve uma overdose causada pelo solvente thinner, passando alguns meses no hospital, onde tem forte referência afetiva até hoje, sendo insistentes os seus pedidos para ir lá visitar as enfermeiras e local. A visita só não acontece porque ele nunca concorda em ir sem a cola.

26.9.2000 - Terça-Feira. Trabalho com Cabuloso, 11 anos, na praça. Contamos suas cica-trizes. Ele deitado no banco com a cabeça no meu colo. Percorremos seu corpo todo com a ponta de seus dedos. Eu conduzia. Contamos em seu corpo mais de 30 cicatrizes. Ele conta onde e como as obteve. Discutimos a partir daí a violência, os porquês das brigas, as conseqüências. Ele sabe que está sozinho na rua, pois seu irmão saiu dela por motivos de segurança. Como é proposta que vá para o Projeto Horta, sendo esse um dos motivos pelo qual 
começamos a contar cicatrizes e refletir sobre a sua vivência na rua, escrevi a palavra Horta em seu braço. Ele identificou as vogais antes de saber qual palavra era. Li para ele o que havia gravado em sua pele, contando como era essa instituição. Ele depois de ouvir e refletir comigo, chegou a dizer que gostaria de ir sim. Quando seria isso não afirmou. Desconversou dizendo ir somente quando pudesse. Logo começou a ironizar quando perguntei quais vogais não estavam na palavra horta. Identificou logo a vogal $\mathrm{u}$, dizendo que $\mathrm{u}$ era de $\mathrm{cu}$. Passou então a falar repetidas vezes. Pulando e sorrindo, colocava o dedo entre uma rodinha que fazia com outros dois dedos de sua outra mão. A princípio ele tentou me intimidar, e quando viu que eu repetia com ele a palavra, sorria num misto de vergonha e euforia. Desenhamos e brincamos juntos com os símbolos e significados das palavras cu e pau.

Notas

1 Centro Erê é o Projeto Alternativo de Apoio a Meninos e Meninas de Rua. Data sua fundação de maio de 1991, publicado no Diário Oficial do Estado de 24 de novembro de 1991. É uma entidade não governamental, mantida por sócios colaboradores e pessoas físicas ou jurídicas que queriam contribuir. Está localizado na rua Melo Morais, $\mathrm{n}^{\circ}$ 180, Centro, Maceió, fone (336-9879). Possui outra unidade, localizada na Comunidade da Vila Brejal (Jardim São Francisco), situada na rua Bela Vista, $n^{\circ} 553$, Levada, Maceió.

2 Para lá são enviados menores infratores com histórico de crimes leves e também graves. Está localizado no bairro do Tabuleiro dos Martins em Maceió, sendo diretamente vinculado à Secretaria de Justiça do Estado.

3 O Complexo Educacional Humberto Mendes é mais conhecido como a "Cidade de Menores". Hoje parcialmente desativado, serve de abrigo a crianças e adolescentes que por motivos vários não possuem um lar. As atividades sócio-educativas não funcionam, estando suas oficinas desativadas já há vários anos. Alguns poucos monitores controlam a entrada e saída dos jovens. Localiza-se no bairro do Tabuleiro dos Martins. É um projeto do Governo do Estado.

4 O Projeto Horta funciona na localidade chamada Ilha de Santa Rita, próximo à cidade de Maceió. É um projeto com orientação religiosa, sendo cuidado por freiras. As crianças e adolescentes são atendidos em regime de abrigo, podendo ir até as casas de suas famílias, se as tiverem, nos finais de semana. São do sexo masculino, e todos devem estar integrados às aulas regulares e atividades artesanais oferecidas pelas oficinas de padaria, fábrica de chinelos e picolés, marcenaria e horta. Os financiadores são europeus.

Cláudia Virgínia Medeiros Almeida é graduada em História pela Universidade Federal de Alagoas. 